\title{
Hubungan Antara Pendapatan Terhadap Kesejahteraan Subjektif Pada Anggota Tni Au Di Kota X
}

\author{
Iqhsan Eko Setiawan. M Ridwan Saputra. Arsepta Kurnia Sandra \\ Pascasarjana Magister Psikologi Universitas Ahmad Dahlan Yogyakarta \\ Email: ighsan_eko@yahoo.co.id, saputramuhammadridwan@gmail.com,arseptaks@windowslive.com
}

\begin{abstract}
This study aimed to examine the relationship between personeel income beetwean subjective well-being on military personeel. A quantitative survey was performed on a sample of personeels $(N=43) T N I A U$ in City X and study documents is used to measure how impact of personeel income to personeel's SWB. The subjective well-being as an independent variable and to measure how subjective well-being correlated each other, this study has used Satisfaction With Life Scale (Diener, 2006) and Positive Affect and Negative Affect Experience (Diener, 2009). Result showed that personeel income is significantly correlate with subjective well-being $(p=0.036$, sig. $<0.05)$. New finding also shows that high and low income are significantly correlate with subjective well-being, limited and recommendation are discussed.
\end{abstract}

Keywords: Subjective well-being, Income

Abstrak

Penelitian ini bertujuan untuk menguji hubungan pendapatan dengan kesejahteraan subjektif pada anggota TNI AU di Kota X. Hasil survei kuantitatif yang dilakukan pada sampel $(\mathrm{N}=43)$ di TNI AU di Kota X dan dokumen studi digunakan untuk mengukur bagaimana dampak pendapatan terhadap SWB. Penelitian ini menggunakan Satisfaction With Life Scale (Diener, 2006) dan Positive Affect and Negative Affect Experience (Diener, 2009). Hasil penelitian menunjukkan bahwa pendapatan berhubungan signifikan dengan kesejahteraan subjektif $(\mathrm{p}=0,036$, sig. $<0,05)$. Temuan baru juga menunjukkan bahwa pendapatan tinggi dan rendah secara signifikan berkorelasi dengan kesejahteraan subjektif.

Kata Kunci: Kesejahteraan Subjektif, Pendapatan

\section{Pendahuluan}

Belakangan ini banyak kajian yang membahas mengenai kesejahteraan. Individu satu dan yang lainnya memiliki penilaian yang berbeda terhadap kualitas kehidupan mereka masing-masing, atau dapat dikatakan untuk menilai kesejahteraan terdapat unsur subjektifitas didalamnya. Penilaian yang berbeda antar setiap individu mengenai kuallitas hidup tersebut disebut dengan subjective well-being atau kesejahteraan subjektif.

Berdasarkan faktor-faktor yang dapat mempengaruhi kesejahteraan subjektif, pekerjaan adalah salah satu faktor yang mampu memprediksi kebahagiaan dan erat kaitannya dengan kesejahteraan subjektif selain keluarga, lingkungan sosial, dan lain-lain (Nassbaum dalam Hogge \& Vanhoutte, 2011).

Hasil temuan fenomena yang ada menunjukkan bahwa terdapat masalah terkait pekerjaan, salah satunya di kalangan TNI. Penelitian yang dilakukan oleh Sulitiriyanto (2011) menunjukkan bahwa, salah satu masalah di kalangan TNI berasal dari faktor ekstenal yang berdampak besar terhadap prajurit, terutama pandangan menjadi seorang prajurit tidak seperti apa yang dibayangkan diawal dan imbalan ekonomi yang diterima terbatas.

Hasil wawancara yang dilakukan di Markas Besar TNI AU di Kota X juga ditemukan beberapa permasalah di kalangan TNI yakni masalah pendapatan dan masalah tugas-tugas yang harus dikerjakan. Terkait permasalahan pelaksanaan dalam menghadapi tugas, anggota TNI yang tidak melaksanakan tugas dari atasannya termasuk dalam kategori pelanggaran disiplin murni. Pelanggaran disiplin murni biasanya dikarenakan ketidaksiapan anggota TNI dalam menjalankan tugas, ini dikarenakan adanya ketidaksesuaian gambaran awal dengan apa yang terjadi dilapangan ketika sudah menjadi anggota TNI. Selain itu, dorongan menjadi anggota TNI bukan berasal dari dalam diri sendiri sehingga tugas-tugas yang ada di TNI dipersepsikan berat dan menjadi beban tersendiri.

Kesejahteraan Subjektif

Kesejahteraan subjektif adalah istilah ilmiah dari kebahagiaan (Diener, 2009). Kesejahteraan subjektif diartikan sebagai evaluasi kognitif dan afektif seseorang (Andrews \& Whitey dalam Diener, 2009). Evaluasi kognitif terlihat dari kepuasan hidup sedangkan evaluasi afektif dinilai dari afek positif dan afek negatif. Afek positif yang tinggi, afek negatif yang rendah, dan kepuasan hidup yang tinggi

Diterima Redaksi: 1-04-2020 | Selesai Revisi: 20-05-2020 | Diterbitkan Online: 1-06-2020 
merupakan gambaran dari tingginya kesejahteraan subjektif (Diener dalam Albuquerque, Lima, Figueiredo \& Matos, 2012). Kesejahteraan subjektif merupakan penilaian individu secara kognitif dan afektif terhadap kualitas kehidupannya secara keseluruhan yang ditunjukkan oleh sedikit banyaknya pengalaman dari kejadian menyenangkan dan tidak menyenangkan yang dialami oleh individu tersebut. Menurut Myers, Diener, dan Nassbaum, terdapat beberapa aspek yang ada pada kesejahteraan subjektif, antara lain yaitu: (1) Kepuasan hidup menurut Diener (Diponegoro, 2013) adalah kemampuan seseorang untuk menikmati pengalaman-pengalaman yang dimiliki dengan kegembiraan. Schimmack (Eid \& Larsen, 2008) menjelaskan bahwa kepuasan hidup sebagai komponen kognitif karena kepuasan hidup didasarkan pada keyakinan evaluatif tentang kehidupan. Individu mencapai kepuasan hidup melalui hubungan dari beberapa komponen kehidupan seperti pekerjaan, keluarga, lingkungan sosial, dan lain-lain (Nassbaum dalam Hogge \& Vanhoutte, 2011); (2) Afek adalah sebuah konsep yang meliputi baik emosi maupun suasana hati. Diener (1984) menjelaskan bahwa terdapat dua jenis afek yakni afek positif dan negatif. Afek positif meliputi berbagai macam perasaan positif diantaranya, kepercayaan diri, minat, harapan, kebanggaan, dan suka cita sedangkan afek negatif meliputi berbagai macam perasaan negatif diantaranya, marah, benci, rasa bersalah, dan kesedihan (Myers \& Diener dalam Eryilmaz, 2012). Afek inilah yang akan terus menerus merefleksikan evaluasi dan kondisi kehidupan seseorang (Diner, 2008).

Afek merupakan komponen dari kesejahteraan subjektif. Kepuasan hidup merupakan bagian dari komponen kognitif untuk menilai kehidupan individu secara menyeluruh. Afek terdiri dari dua jenis yaitu afek positif yang merupakan perasaan menyenangkan dan afek negatif yang meliputi perasaan tidak menyenangkan, keduanya merupakan komponen yang mampu menggambarkan tingkat kesejahteraan subjektif seseorang.

Berdasarkan analisis pengukuran kesejahteraan subjektif faktor yang mampu memberikan kontribusi kebahagiaan yakni uang, usia dan faktor lain lainnya (Diener \& Suh 2000). Pendapat lain juga dikemukakan oleh Hooghe dan Vanhoutee (2011) yang menjelaskan bahwa kesejahteraan subjektif dipengaruhi oleh beberapa faktor seperti usia dan jenis kelamin, struktur keluarga, hubungan sosial, kondisi materi, struktur kepribadian, dan tingkat komunitas. Berdasarkan faktor-faktor tersebut, yang dapat mempengaruhi kesejahteraan subjektif terkait dengan variabel penelitian ini adalah kondisi materi.

Kondisi materi dapat dibedakan menjadi dua bagian yang saling berkaitan yaitu, penghasilan dan pekerjaan, berikut penjelasannya: (1) Penghasilan, beberapa hasil penelitian penghasilan dapat meningkatkan kesejahteraan subjektif individu. Diener (Snyder \& Lopez, 2002) menjelaskan bahwa pendapatan memiliki pengaruh terhadap kesejahteraan subjektif. (2) Pekerjaan, Lucas (2004) menemukan bahwa individu yang tidak memiliki pekerjaan memiliki efek negatif pada kesejahteraan subjektif. Pekerjaan tidak hanya sekedar mencari nafkah, melainkan dapat mendasari realisasi diri yang merupakan kunci dari kesejahteraan subjektif (Hooghe \& Vanhoutte, 2011).

Jugde, Klinger, dan Warr (Weiten, 2013) menjelaskan bahwa banyak orang mengeluh tentang pekerjaan mereka, individu tidak memiliki ekspektasi bahwa pekerjaan sebagai sumber utama kebahagiaan.Faktor yang mempengaruhi kesejahtreraan subjektif diantaranya, usia dan jenis kelamin, struktur keluarga, hubungan sosial, kondisi materi, struktur kepribadian, dan tingkat komunitas. Namun peneliti fokus kepada faktor kondisi materi yang dibedakan menjadi penghasilan dan pekerjaan, karena terkait dengan permasalahan yang ditemukan dilapangan.

Pendapatan

Suyanto (2000) mendefinisikan pendapatan sebagai sejumlah dana yang diperolah dari pemanfaatan faktor produksi yang dimiliki individu. Sumber pendapatan tersebut diantaranya berasal dari sewa kekayaan yang digunakan oleh orang lain, misalnya menyewakan rumah, tanah, kemudian upah atau gaji karena bekerja kepada orang lain ataupun menjadi pegawai negeri, bunga karena menanamkan modal di bank ataupun perusahaan, misalnya mendepositokan uang di bank dan membeli saham, dan hasil dari usaha wiraswasta, misalnya berdagang, bertenak, mendirikan perusahaan, ataupun bertani. Pendapatan juga dapat diartikan sebagai seluruh penerimaan seseorang sebagai balas jasanya dalam proses produksi. Balas jasa tersebut bisa berupa upah, bunga, sewa, maupun, laba tergantung pada faktor produksi pada yang dilibatkan dalam proses produksi (Sudremi, 2007).

Hasil pemaparan diatas dapat disimpulkan bahwa pendapatan adalah sejumlah dana yang didapatkan dari pemanfaatan yang dimiliki individu yang bisa berasal dari balas jasa yang telah diberikan, bisa dalam bentuk sewa kekayaan, gaji karena berkerja, menanamkan modal, dan hasil dari wiraswasta. 
Keterkaitan antara Pendapatan dan Kesejahteraan Subjektif

Pendapatan memiliki keterkaitan erat dengan kesejahteraan subjektif, sebab kondisi materi individu berdampak pada kesejahteraan individu tersebut. Seperti penelitian yang dilakukan oleh Diener (Snyder \& Lopez, 2002) yang menemukan bahwa pendapatan memiliki pengaruh terhadap kesejahteraan subjektif. Temuan lain juga menunjukkan bahwa Penghasilan dalam taraf tertentu mampu mempengaruhi taraf kesejahteraan subjektif manusia (Diponegoro, 2013).

Hipotesis

Berdasarkan pemaparan singkat di atas, maka hipotesis yang diajukan pada penelitian ini yaitu diprediksikan akan ada: hubungan antara pendapatan dan kesejahteraan subjektif. Tinggi rendahnya pendapatan berhubungan dengan tinggi rendahnya kesejahteraan subjektif pada anggota TNI AU di Kota $X$.

\section{Metode Penelitian}

Penelitian ini akan menggunakan desain penelitian korelasional dengan melibatkan variabel dependen kesejahteraan subjektif dan variabel independen pendapatan. Penelitian korelasional merupakan penelitian yang dilakukan untuk mengetahui tingkat keterhubungan antara dua variabel atau lebih (Arikunto, 2010). Subjek yang turut berpartisipasi dalam penelitian ini adalah anggota TNI AU di Kota $X$, dengan jumlah pastisipan sebanyak 43 orang.

Skala kesejahteraan subjektif diadopsi dari Scale of Positive and Negative Experience (Diener, 2009) dengan 12 aitem yang keseluruhannya merupakan aitem favorable, dan The Satisfaction with Life Scale (Diener, 2006) dengan lima aitem yang diantaranya merupakan empat aitem favorable dan satu aitem unfavorable yang disusun oleh Diener. Aspek-aspek kesejahteraan subjektif yang diukur antara lain yaitu kepuasan hidup, afek positif, dan afek negatif. Prosedur skoring pada skala kesejahteraan subjektif dilakukan pada setiap alat ukur yaitu The Satisfaction with Life Scale dan Scale of Positive and Negative Experience. Pada alat ukur Scale of Positive and Negative Experience, afek seimbang dicari terlebih dahulu dengan cara skor afek negatif dikurangi skor afek positif.

Studi dokumen merupakan teknik pengumpulan data yang tidak langsung ditujukan kepada subjek penelitian (Soehartono, 1995). Penerapan studi dokumen dilakukan dengan cara melihat data personalia terkait gaji anggota berdasarkan pangkat. Selain itu, penggunaan studi dokumen dilakukan guna melengkapi data responden yang tidak mencantumkan golongan sehingga data dapat diolah.

Prosedur pengambilan data penelitian diawali dengan meminta persetujuan dari responden untuk berpartisipasi dalam penelitian, peneliti berkerjasama dengan pihak kampus membuat surat izin penelitian yang akan diberikan kepada TNI AU di Kota X. Subjek penelitian dipilih berdasarkan kriteria yang sudah disepakati dan penelitian dilakukan di TNI AU di Kota X. Responden diminta untuk menjawab seluruh pertanyaan pada skala yang sudah diedarkan peneliti. Kompensasi yang diberikan peneliti kepada responden berupa pengetahuan diri terkait dampak penghasilan terhadap kesejahteraan subjektif TNI AU di Kota X, sehingga penelitian ini diharapkan dapat memberikan kontribusi dalam memahami diri dan cara untuk meningkatkan kualitas diri.

\section{Hasil dan Pembahasan}

Penelitian ini dilakukan bertujuan untuk mengetahui apakah ada hubungan antara pendapatan pada kesejahteraan subjektif anggota TNI AU, bagaimana pendapatan mampu mempengaruhi kesejahteraan subjektif. Berdasarkan hasil uji hipotesis dapat dikatakan bahwa terdapat hubungan antara pendapatan pada kesejahteraan subjektif anggota TNI AU (lihat Tabel 2).

Uji Normalitas

Uji normalitas dilakukan bertujuan untuk mengetahui sebaran distribusi data penelitian normal atau tidak normal. Pada penelitian ini uji normalitas sebaran menggunakan Test of Normality Shapiro-Wilk, karena subjek yang berpartisipasi dalam penelitian ini sejumlah 43 subjek (df $<50$ ). Data dikatakan normal jika $\mathrm{p}>0.05$ dan data dikatakan tidak normal jika $\mathrm{p}<0.05$. Hasil uji normalitas dapat dilihat pada tabel berikut: 


\begin{tabular}{cccc}
\multicolumn{4}{c}{ Tabel. 1 Hasil Uji Normalitas } \\
\hline Variabel & Statistic & Sig. (p) & Ket. \\
\hline $\begin{array}{c}\text { Kesejahteraan } \\
\text { Subjektif }\end{array}$ & 0.980 & 0.638 & Normal \\
\hline
\end{tabular}

Hasil uji normalitas menunjukkan bahwa sebaran distribusi data kesejahteraan subjektif $\mathrm{p}=0.638$ ( $\mathrm{p}$ >.05). Hal ini menjelaskan bahwa sebaran distribusi data variabel kesejahteraan subjektif normal

Uji Hipotesis

Uji hipotesis dilakukan bertujuan untuk mengetahui apakah terdapat hubungan antara pendapatan dan kesejahteraan subjektif pada Anggota TNI AU di Kota X. Uji hipotesis menggunakan uji Pearson Correlation, Two Tailed, karena sebaran distribusi data normal. Variabel dapat dikatakan berhubungan jika $\mathrm{p}<0.05$. Hasil uji hipotesis dapat dilihat pada tabel berikut:

\begin{tabular}{cc}
\multicolumn{2}{c}{ Tabel. 2 Hasil Uji Hipotesis } \\
\hline Variabel & Sig. p \\
\hline $\begin{array}{c}\text { Kesejahteraan Subjektif * } \\
\text { Pendapatan }\end{array}$ & 0.036 \\
& \\
\hline
\end{tabular}

Hasil uji hipotesis menunjukkan bahwa hipotesis yang diajukan pada penelitian ini diterima, yaitu terdapat hubungan antara pendapatan dan kesejahteraan subjektif pada anggota TNI AU di Kota X. Hal ini dapat dilihat dari $\mathrm{p}=0.036(\mathrm{p}<0.05)$ untuk kesejahteraan subjektif dan pendapatan.

\begin{tabular}{lcc}
\multicolumn{3}{c}{ Tabel. 3 Hasil Uji T-Test } \\
\hline & Gaji Pokok & Mean \\
\hline \multirow{3}{*}{ SWB } & Kelompok 1 & 3.003 \\
& Rp. 2.570.800-2.819.500 & \\
& Kelompok 2 & 3.250 \\
& Rp. 3.292.000-3.610.500 & \\
\hline
\end{tabular}

Hasil Uji T-Test terdapat perbedaan antara Kelompok 1 dan Kelompok 2 terkait dengan hubungan antara kesejahteraan subjektif dan pendapatan, Kelompok 2 memiliki kesejahtreaan subjektif lebih tinggi dibandingkan dengan Kelompok 1. Hal ini dapat dilihat dari mean 3.250 untuk Kelompok 2 dan 3.003 untuk Kelompok 1.

Hasil temuan pada penelitian ini sejalan dengan penelitian Diener (Snyder \& Lopez, 2002) menemukan bahwa pendapatan memiliki pengaruh terhadap kesejahteraan subjektif. Pendapatan yang diperoleh seorang personeel anggota TNI AU mampu memberikan kontribusi terhadap kesejahteraan subjektif pada anggota, hal ini dapat dilihat dari hasil penelitian yang dilakukan bahwa pendapatan berkorelasi positif dengan kesejahteraan subjektif. Anggota yang memperoleh pendapatan tinggi memiliki taraf kesejahteraan subjektif lebih tinggi jika dibandingan dengan anggota yang memperoleh pendapatan pendapatan rendah. Hal ini sejalan dengan temuan bahwa penghasilan dalam taraf tertentu mampu mempengaruhi taraf kesejahteraan subjektif manusia (Diponegoro, 2013).

\section{Kesimpulan}

Berdasarkan hasil penelitian yang diperoleh, dapat disimpulkan bahwa tinggi rendahnya kesejahteraan subjektif pada anggota TNI AU di Kota X mampu dijelaskan oleh tinggi rendahnya pedapatan. Meskipun proses penelitian ini secara keseluruhan dapat berjalan dengan lancar, masih banyak terdapat kekurangan yang kedepannya diharapkan dapat menjadi evaluasi untuk penelitian selanjutnya. Penelitian ini, terdapat kesulitan ketika proses pemberian instruksi kepada subjek penelitian, peneliti harus memastikan kembali satu persatu apakah responden mengisi skala dengan benar dan telah mengisi identitas secara lengkap sekaligus memahami instruksi pengisian skala. Selain itu, peneliti memiliki kesulitan pada waktu penyebaran skala mengingat jumlah responden anggota TNI AU di Kota X yang terbatas sehingga tidak dapat membagikan skala pada lebih dari 43 responden. 


\section{Daftar Rujukan}

Albuquerque, I., Lima, M. P., Figueredo, C. \& Matos, M., 2012. Subjective Well-Being Structure: Confirmatory Factor Analysis in A Teachers Portuguese Sample. Social Indicators Research, 105, 569-580.

Arikunto, S., 2010. Prosedur penelitian: Suatu Pendekatan Praktik (Edisi Revisi). Jakarta: Rineka Cipta.

Diener, E. 1984. Subjective Well-Being. Psychological Buletin. American Psychological Association Vol. 95. No. 3. 542-575.

Diener, E., 2006. Understanding Scores on The Satisfaction with Life Scale.

Diener, E., 2009. Assessing well-being: The Collected Works of Ed Diener. New York: Springer.

Diener, E., \& Biswas-Diener, R., 2008. Happiness: Unlocking the Mysteries of Psychological Wealth. Malden, MA: Blackwell.

Diener, E., \& Suh, E., 2000. Culture and Subjective Well-Being. Cambridge, MA: MIT Press.

Diponegoro, A., M., 2013. Psikologi Konseling dan Islam. Yogyakarta: Multi Presindo.

Eid, M., \& Larsen,R. J., 2008. The science of subjective well-being. New York: Guilford.

Eryilmaz, A., 2012. A Model of Subjective Well-Being for Asolescents in High School. Journal of Happiness Study, 13, 275-289.

Hooghe, M. \& Vanhoutte, B., 2011. Subjective Well-Being and Social Capital in Belgian Communities: The Impact of Community Characteristics on Subjective Well-Being in Belgium. Social Indicators Research, 100, 17-36.

Lucas, R. E., Clark, A. E., Georgellis, Y., \& Diener, E., 2004. Unemployment Alters the Set-Point for Life Satisfaction. Psychological Science, 15, 8-13.

Snyder, C. R. \& Lopez, S. H., 2002. Positive Psychological Assessment: A Handbook of Model and Measures. Washington, DC: American Psychological Association.

Soehartono, I., 1995. Metodel Penelitian Sosial. Bandung: PT. Remaja Rosdakarya.

Sudremi, Y., 2007. Pengetahuan Sosial Ekonomi Kelas X. Jakarta: Bumi Aksara.

Suyanto., 2000. Refleksi dan Reformasi Pendidikan di Indonesia Memasuki Milenium III. Yogyakarta: Adicita. 